\title{
Hypermodernism as Deceleration, Re-stabilisation and Reconciliation
}

\author{
Marcin Trepczyński \\ (University of Warsaw, Institute of Philosophy)
}

\section{Introduction}

In view of the claims of some thinkers that we can speak about "the end of the postmodern" ${ }^{2}$ or that postmodernity "is over", ${ }^{3}$ it is reasonable to ask about the dominant indicators of today's times and to ask whether it is accurate to describe them using concepts and labels developed to define the last decades of the 20th century. Such reflection is an element of a broader consideration of the human situation. It is important from the point of view of such questions as: how do we live and think, where do we go, who are we. From this perspective, reflection on the situation of individuals and societies has great philosophical significance.

In this article I will try to address the main diagnoses and concepts concerning our times provided by thinkers referring to notions such as "postmodernism", "the postmodern", "after modernity" or "liquid modernity". I will show that, at least today, they are insufficient and inadequate. I will also try to point to present attitudes which should be taken into account in any description of our times and to offer a proper name for them. Finally, I will briefly sketch how it is combined with the philosophical questions mentioned above.

1 The key concepts of this article were presented in my talk at the conference Around Hypermodernism, held at the Faculty "Artes Liberales" of the University of Warsaw on June 14, 2018.

2 Cf. J. Toth, The Passing of Postmodernism: A Spectroanalysis of the Contemporary, SUNY Press, Albany 2010.

3 L. Hutcheon, The Politics of Postmodernism, Routledge, New York-London 2002, pp. 165-166. 
In what follows I will discuss such terms as "metamodernism", "hypermodernism", "hypermodernity" and "supermodernity" which (except for the first one) have been present in academic reflections since the early 1990s. Let us just note here that those terms were first used in 1992 by Mark Węgierski ("hypermodernism") and by Marc Augé ("supermodernity", originally: surmodernité) and in 2004 by Gilles Lipovetsky and Sébastien Charles ("hypermodern times", originally: les temps hypermodernes, "hypermodernity", originally: l'hypermoderne) as well as by Nicole Aubert ("hypermodern individual", originally: l'individu hypermoderne) who under this title published an edited collection of papers presented during a conference held in 2003 in Paris. ${ }^{4}$ Finally, it should be noted that in the last decade the term "metamodernism" has been exploited by many authors and extensively discussed by Timotheus Vermeulen and Robin van den Akker in 2010. ${ }^{5}$

\section{Accelerated or decelerated modernity?}

The first statement I would like to present and comment on is that today's modernity is not accelerated, but decelerated. Some thinkers of the end of the 20th century have claimed that the speed of changes is constantly growing. For instance, Węgierski pointed out that especially technological changes grow "exponentially" (so in the language of mathematics according to the following equation: $f(x)=a^{x}$, where " $x$ " is a variable representing time and " $a$ " some number of changes). ${ }^{6}$ This opinion was shared and developed by, for instance, the recognized

4 See: M. Węgierski, The Dilemma of Hypermodernity, "Perspectives" 1992, Vol. 5. [Polish translation: Dylemat hipermodernizmu, “Zielone Brygady. Pismo ekologów” 1993, No. 4], available online: http://literatefreedom.org/dilemma-of-hypermodernity; M. Augé, Non-Lieux: Introduction à Une Anthropologie de la Surmodernité, Seuil, Paris 1992 [English translation: 1995: Non-Places: Introduction to an Anthropology of Supermodernity, transl. J. Howe.]; G. Lipovetsky, S. Charles, Les temps hypermodernes, Grasset \& Fasquelle, Paris 2004 [English translation: Hypermodern Times, transl. A. Brown, Polity Press 2005]; S. Charles, L'hypermoderne expliqué aux enfants: Correspondance 2003-2006, Liber, Montréal 2007; N. Aubert (ed.), L'Individu Hypermoderne, Eres, Ramonville-Saint-Agne 2004; N. Aubert, La Société Hypermoderne, Une Société par Excès?, in: La Société Hypermoderne, Ruptures et Contradictions, ed. N. Aubert, L'harmattan, Paris 2010, pp. 23-34.

5 T. Vermeulen, R. van den Akker, Notes on Metamodernism, "Journal of Aesthetics \& Culture" 2010, Vol. 2, No. 1, 5677.

6 "It is plain to see that the amount of theoretical scientific knowledge (that is, in the 'hard' sci- 
inventor and futurist Raymond Kurzweil who in the introductory paragraph to his essay from 2001 claims that:

An analysis of the history of technology shows that technological change is exponential, contrary to the common-sense 'intuitive linear' view. So we won't experience 100 years of progress in the 21st century - it will be more like 20,000 years of progress (at today's rate). The 'returns,' such as chip speed and cost-effectiveness, also increase exponentially. There's even exponential growth in the rate of exponential growth. Within a few decades, machine intelligence will surpass human intelligence, leading to the Singularity - technological change so rapid and profound it represents a rupture in the fabric of human history. The implications include the merger of biological and nonbiological intelligence, immortal software-based humans, and ultra-high levels of intelligence that expand outward in the universe at the speed of light. ${ }^{7}$

In my opinion, Węgierski's diagnosis is not valid today and Kurzweil's assumptions and predictions are exaggerated. Let us refer to the business analyst, futurist and physicist Theodore Modis, a strong opponent of such ideas, who put it clearly that "the concept of a Singularity as described in Ray Kurzweil's book cannot happen for a number of reasons" and stated in 2012 that:

The exponential pattern of change witnessed up to now dictates more milestone events during year 2025 than witnessed throughout the entire 20th century! But such events are already overdue today. If, on the other hand, the change growth pattern has indeed been following an S-curve, then the rate of change is about to enter a declining trajectory; the baby boom generation will have witnessed more change during their lives than anyone else before or after them. ${ }^{8}$

ences) is growing exponentially, as is the number of chemicals / substances / tools / devices which are being produced, as a result of the growth and practical application of such scientific theory. Ultimately, these technological processes are fuelled by the market-economies of (primarily) North America, Western Europe, and now the Pacific Rim countries" (M. Węgierski, The Dilemma..., introduction).

7 R. Kurzweil, The Law of Accelerating Returns, "Kurzweil. Accelerating Intelligence: Essays", https://www.kurzweilai.net/the-law-of-accelerating-returns.

8 Th. Modis, Why the Singularity Cannot Happen, in: Singularity Hypotheses, ed. A.H. Eden et al., Springer, Berlin-Heidelberg 2012, p. 312, DOI: 10.1007/978-3-642-32560-1_16. 
And to address the rates of innovation we should mention the physicist Jonathan Huebner who in 2004 counted that:

The rate of innovation peaked in the year 1873 and is now rapidly declining.

We are at an estimated $85 \%$ of the economic limit of technology, and it is projected that we will reach $90 \%$ in 2018 and $95 \%$ in $2038 .{ }^{9}$

Also, if we focus on the pace of social changes, we can notice some signals of a downturn. Let us quote Thomas K. Rudel and Linda Hooper who in an article from 2005, after referring to the opinions on the accelerated pace of change, especially social change, stated that:

While the above observations may collectively convey an impression of inevitability about accelerating rates of social change, rates can slow down as well. For example, rates of urbanization in the developing world accelerated until 1980, but in recent years they have slowed down (Brockerhoff, 1999). ${ }^{10}$

Finally, to examine whether exponential growth is omnipresent it seems like a good idea to also consider specific areas of development, such as the use of broadband internet and fibre optics or electromobility. Taking Poland as an example, we can see that despite technological possibilities the use of fibre optics and broadband internet is still limited. The most powerful operator in Poland (where the population stands at over 38 million citizens) noted about 140,000 clients choosing fibre optics in 2017 and planned great investments to cover up to 3.5 million households until the end of 2018 and up to 5 million in 2020. However, let us point out that the internet is present in Poland since the mid-1990s, that fibre was invented in the late 1970s and that today this technology is still accessible only for a minority of citizens. What is more, this programme probably would not have been implemented if not for funding from the European Union. So, in fact this change is being hastened by political decisions and public funds.

9 J. Huebner, A Possible Declining Trend for Worldwide Innovation, "Technological Forecasting and Social Change" 2005, Vol. 72, No. 8, p. 980.

10 Th.K. Rudel, L. Hooper, Is the Pace of Social Change Accelerating? Latecomers, Common Languages, and Rapid Historical Declines in Fertility, "International Journal of Comparative Sociology" 2005, Vol. 46, No. 4, p. 276, DOI: 10.1177/0020715205059204. See also the article these authors refer to: M. Brockerhoff, Urban Growth in Developing Countries: A Review of Projections and Predictions, "Population and Development Review" 1999, Vol. 25, No. 4, pp. 757-778. 
As regards electromobility, although electric buses are common in the public transport of the main cities and electric cars are present on Polish roads, this solution is still not common. The Polish Law on Electromobility and Alternative Fuels (Journal of Laws 2018, item 317) defines in article 60 the minimal number of battery charging points for 2020 in several types of towns and communities. However, as the Polish Association for Alternative Fuels assesses, electric cars will dominate on the Polish market in 2035 and, according to the Bloomberg agency, in the whole world the breakthrough number of 100 million electric cars will be reached in 2030. This means that for the common usage of an invention which is well known now we need to wait more than 10 years. It is also significant that this change needs to be hastened by the government.

This shows that there are some retardants which cause deceleration: although technologies are known, they are not being applied as quickly as we could expect. One of the reasons could be that companies selling new technologies have understood that on average people do not like fast changes. Another reason could be that the application of new technologies (which often entails expensive infrastructure) is usually a great investment. Finally, it seems more reasonable to sell what has been produced to as great a number of consumers as possible before launching new technologies. This means that the growth of the common usage of new technologies is regulated by economy rather than by technological development. To conclude, in my opinion today the rules of economy can be the cause of a deceleration of possible growth of changes in people's lives. Of course, the examples presented above are limited to the situation in Poland, so in order to generalise and state this conclusion firmly, it would be necessary to collect data from other countries.

As a side note to these remarks, it would be interesting to confront the opinions presented above with the people's subjective impressions. Of course, it would be methodologically problematic and in order to obtain credible results it would be necessary to conduct a serious representative study. If we decided to do it, we should note that for those who are not used to new inventions and new technologies those changes may seem both too fast and dangerous, but at the same time other people may be awaiting new solutions which will meet their needs and may perceive the pace of changes as too slow. That is to say that people perceive changes against the background of what they expect. Thus, we should not ask them about what they wish to be fulfilled, but what they foresee will happen according 
to the nature of development, as they imagine it based on rational assessment. Hence, if people generally follow changes, they should expect that any new possibility will open up a wide range of new possibilities, so they could expect growth to be exponential. Therefore, the following research question would be formulated: does the majority of people think that growth is faster or slower than they could have expected (or foreseen)? Of course, first it would be necessary to establish the population of respondents, which may be problematic, and to determine what kind of changes are referred to in such a question. Let us finally remark that we can also point to another interesting background against which respondents (even unconsciously) could assess the pace of changes, namely popular visions created within mass culture by futurologists and filmmakers (Stanley Kubrick's film 2001: A Space Odyssey from 1968 can serve as a symbol of unfulfilled assumptions about the future). Through those visions the recipients or participants of this culture are accustomed to ideas such as intelligence explosion (according to the concept of technological singularity) or transhumanism (i.e. in the meaning offered by the creators of Project 2045 presented to the public at the website 2045.com) and the common presence and usage of artificial intelligence. It seems possible that those who take such visions seriously can be under the impression that we are still a few steps behind in scientific, technological and social development. Anyway, as has been mentioned, a credible answer may only be delivered by a serious representative study.

We should notice that the way people perceive the pace of development matters to the way they understand their ontological ${ }^{11}$ situation. The following philosophical question can be posed in this context: whether a human being is co-defined by a pursuit of change and by adjusting or getting accustomed to changes, or on the contrary: by waiting for changes and perhaps fighting for them? If we assume that in our times people feel that today's modernity is accelerated, the ontological situation of human beings, depending on the attitude to changes, may be described by, for instance: fear of change, tension-to-adjust, calmness-of-a-proper-rhythm, joy-of-acceleration. Perhaps the basis for the worries about

11 I adopt here the Heideggerian concept of ontology, as T. Vermeulen and R. van den Akker in the passages quoted in the last section. I present here some kinds of "descriptors" which are construed in a similar way to Heidegger's ones, but of course they are not intended to supplement those proposed by Heidegger who described the being of every Dasein, whereas those descriptors are intended to only characterise the being of a human being (or Dasein) in certain situations. 
the increasing pace is not formed by only pessimistic predictions but also a kind of ontological tension rooted in the feeling that changes are coming too fast. On the other hand, if we assume that our modernity is decelerated, such descriptors, beside the case of calmness-of-a-proper-rhythm, will not be appropriate. And if people find changes too slow and expect them to come, something like an expectation-, or even pressure-, -towards-change can occur. Furthermore, let us remark that the idea of Singularity creates a horizon not just for several human beings, but a common one for all mankind. According to this concept, this historical point will end human domination. Hence, we could claim that such a situation produces a new collective ontological property, which is beingtowards-Singularity.

\section{Fixed points in liquidity}

The second claim of this article is that today's "liquid" modernity seems to be seeking fixed points. Liquid modernity (as opposed to solid modernity and also fluid modernity) and light modernity (as opposed to heavy modernity with its heavy capitalism) was illustrated by Zygmunt Bauman above all else by the example of the rules adopted by the Microsoft Corporation. He quoted the economist Daniel Cohen who analysed the functioning of this company and observed that a person "who starts a career in Microsoft has no idea where it is going to end", whereas "starting with Ford or Renault, entailed on the contrary the nearcertitude that the career would run its course in the same place". He also referred to Richard Sennet who after meeting Bill Gates in Davos reported that Gates preferred "positioning oneself in a network of possibilities rather than paralyzing oneself in one particular job" and was prepared to "destroy what he has made, given the demands of the immediate moment". Finally he combined it with such new ideas as working with mobility connected with travelling by planes with "cabin luggage only, which includes no more than a briefcase, a cellular telephone and a portable computer". ${ }^{12}$ This was only one example out of many others showing how today's liquid modernity is opposed to "durable structures" and to fixing work to certain stable places.

12 Cf. Z. Bauman, Liquid Modernity, Polity Press, Cambridge 2000, pp. 58, 124. 
To some extent Bauman's diagnosis seems accurate, although he has not supported it by sufficient empirical data. Nevertheless, we can assume that at least in some countries the technological possibility which enabled many people to work almost everywhere and be free from long-term contracts caused a great social change. No matter whether we perceive it as a blessing or a curse, many people follow such a path and many employers (even in the public sector) prefer shorttime contracts and flexible structures in their companies.

However, even if Bauman was right when describing the situation of some societies of the last decades of the 20th century, it also seems that this change has reached some end-point and a rational balance has been found between flexibility and other values which have come to be appreciated in recent years by employers, such as: well-trained, implemented, proven and trusted employees, an experienced team, high motivation based on stability and identification with the company. In this light it is worth evoking the analyses concerning creating a core workforce in start-ups, conducted by Howard E. Aldrich and Martin Ruef. Among the many advantages and disadvantages of hiring full-time permanent employees versus part-time temporary employees in start-ups, they pointed out that part-time employees lose the knowledge "learned by doing", whereas permanent workers keep it in their firms. What is more, according to these researchers, part-time temporary employees "remain 'users' in their orientation to the organization, lessening their interest in supporter-like behavior". Finally, they explicitly referred to the value of stability and argued that "continually hiring new employees to replace the departing temporary employees also lowers organizational stability". ${ }^{13}$ It is significant that, as they claim, benefits from hiring permanent rather than temporary employees were reflected in empirical studies:

Consequently, the available evidence suggests that most founders concentrate on hiring full-time employees. For example, Aldrich and Langton (1998) found that only 14 percent of the 229 firms in their Vancouver sample began with part-time employees. ${ }^{14}$

13 H.E. Aldrich, M. Ruef, Organizations Evolving, Sage Publications, London 2006, p. 97.

14 H.E. Aldrich, M. Ruef, Organizations..., p. 98. See the results in the quoted article: H.E. Aldrich, N. Langton, Human Resource Management Practices and Organizational Life Cycles, in: Frontiers of Entrepreneurship Research 1997, ed. Paul Reynolds et al., Babson College, Center for Entrepreneurial Studies, Babson Park, MA 1998, p. 354. 
To oppose Bauman's diagnosis, at least as being pertinent to our times, it is worth quoting Stewart Clegg and Carmen Baumeler who propose to focus on organisations rather than on consumers in order to see that there are structures that do not undergo liquefaction. As these analysts notice:

Flexibility, uncertainty and undecidability do not spread liquidly across all organizations. For those in the advanced societies still consigned to the state bureaucracies of schools, hospitals and the welfare sector, the private sector bureaucracies of the call-centre or the declining branches of industrial capitalism, far more regulation, standardization and linearity will be on offer than is hyped in the liquid world, even as it presents itself in simulacra of the markets taken to characterize liquidity. ${ }^{15}$

At this point we should also touch on the strong criticism voiced against the main claims of Bauman. Beside the fact that some scholars refer to his work as "sociology as art" rather than "sociology as science", ${ }^{16}$ others, for instance Raymond L.M. Lee, point out that Bauman's use of the "liquid metaphor" "neglects the possibility of re-solidification across a wide spectrum of social and political conditions" and that the trajectory of modernity formed by such an understanding of liquidity "denies the reappearance of solidity because it reaffirms the Marxian notion of melting solids and diminishes the scope of agency in the study of social change". ${ }^{17}$ Finally, after claiming that "Bauman's portrayal of communal breakdown, consumer mania and individualistic despair may come to be seen as a caricature rather than a nuanced description of complex social processes in late modernity", this author remarks that:

Data from various empirical studies suggest that re-embedding is possible in the midst of disembedding. By focusing on the possibility of re-solidification, these studies emphasize the need to address the role of agency in confronting the challenges posed by the processes of de-differentiation. ${ }^{18}$

15 S. Clegg, C. Baumeler, Essai: From Iron Cages to Liquid Modernity in Organisational Analysis, "Organisation Studies" 2010, Vol. 31, No. 12, p. 8.

16 M. Davis, Liquid Sociology, "Sociology" 2008, Vol. 42, No. 6, p. 1238.

17 R.L.M. Lee, Modernity, Solidity and Agency: Liquidity Reconsidered, "Sociology" 2011, Vol. 45, No. 4, p. 651.

18 R.L.M. Lee, Modernity, Solidity and Agency..., p. 662. 
It is also significant that the latest studies report a clear change in people's attitudes in favour of values, which is often called "The Values Revolution". According to a report of the organization Global Tolerance, founded mainly on qualitative research which sampled 2,126 individuals across the United Kingdom, this revolution "is particularly apparent in the millennial generation (those born between 1981 and 1996)". As we read in this publication: "A whopping 84\% of millennials consider it their duty to make a positive difference through their lifestyle and $61 \%$ are concerned about the state of the world and feel personally responsible to improve it". ${ }^{19}$ And in the whole sample "nearly three quarters want to see more transparency and $81 \%$ more accountability". The authors of the report seem to perceive this change as real and deep ("The Values Revolution has truly arrived, reshaping our own lives as well as the organisations around us"), so they conclude that employees should follow these trends: "Organisations that want to succeed in a values-driven world must start at the core, weaving values into their strategy, operations and communications". ${ }^{20}$ Let us add that there are economists who underline that narratives referring to such values are essential also from a pragmatic point of view. For instance, in the conclusions of one of the white papers published by the World Economic Forum we find the following statement:

The values of human dignity, common good and stewardship are potentially vital drivers of the new narrative that the current global challenges call for. Such a narrative, communicated to the wider public by a vanguard living this narrative, appears essential to dismantle current social boundaries and thereby generate a willingness to cooperate. ${ }^{21}$

Of course, we cannot conclude on this basis that earlier people had not adhered to values. What can be said here is that - according to the mentioned diagnosis - millennials recognize the importance of "values" (in fact: other values than e.g. money and narrowly understood personal welfare) more than had been the case with earlier generations. It would mean a shift in people's attitudes

Global Tolerance, The Values Revolution (report), London 2015, p. 3.

Global Tolerance, The Values..., p. 11.

D. Malan et al., Values and the Fourth Industrial Revolution: Connecting the Dots between Value, Values, Profit and Purpose, World Economic Forum, Sept. 2016, p. 27, DOI: 10.13140/ RG.2.2.28917.17128. 
towards specified beliefs about what is important and towards common goals, hence - in my opinion - towards stability.

What is more, it seems that people, besides enjoying some benefits of flexibility and independence from structures, on average need to have something stable and solid which will help them conduct a balanced life. ${ }^{22}$ Perhaps their situation does not have to be fixed forever, but they are generally expected to be stable to provide relative security. Apart from the liquidity observed in contemporary societies, we can still notice such relatively stable points as: family and friends relationships, communities which people identify with, public institutions, legal institutions and law in general which protects general rules of social coexistence and secures the certainty of trading. Again, even if we argue that, despite the fact of increasing liquefaction, people also had such needs in the last decades of the 20th century, it seems that today the idea of a balanced life is more explicitly expressed and promoted and has become a real factor defying liquefaction and supporting stability.

Finally, let us mention a proposal made by Sébastien Charles as it could be considered one of the symptoms of seeking some necessary fixed points. Charles, after describing one of the visions of hypermodernity together with Gilles Lipovetsky, ${ }^{23}$ pointed out the need of a new social contract, adopted for purely pragmatic reasons and based on four principles concerning: human rights (liberation and valorisation of the individual), democracy, free market, techno-scientific development. ${ }^{24}$ Even though this author writes these principles "with small letters", as he does not treat them as signs of absolute narratives, but instead offers them as a basis which is necessary for an optimal state of Western societies.

22 Cf. K. Hoffmann-Burdzińska, M. Rutkowska, Work Life Balance as a Factor Influencing Well-Being, "Journal of Positive Management" 2015, Vol. 6, No. 4, pp. 87-101, esp. pp. 91-94 and the literature quoted.

23 G. Lipovetsky, S. Charles, Les temps...

24 "First principle: liberation and valorization of individual within the framework of the legal paradigm which is set up in the seventeenth century, notably in the form of the social pact developed by Hobbes in Leviathan", which "corresponds to the theoretical invention of human rights which will gradually become more practical". "Second principle: promotion of democracy as the only viable political system that combines individual freedom and collective security. Third principle: promotion of the market as a regulating economic system with all the virtues since it contributes to peace between nations and to individual and collective wealth. Fourth principle: technoscientific development conceived as a panacea to the difficult work of men and as a guarantee of the health of human population" (S. Charles, L'hypermoderne expliqué..., pp. 16-17). 
To sum up, if Bauman's diagnosis of the end of the 20th century, which he had labelled as "liquid modernity", was to some extent right and we really did experience the process of "liquefaction" on many levels of social functioning, we can now record the opposite tendency in present times, namely seeking re-stabilisation and re-solidification, both in reality (talking about the practice of organisations) and in people's convictions and ideas (talking about values which are not only widely adopted, but also expressed as banners of the so-called Revolution of Values). Such a change is philosophically significant, not only from the social but also from the individual perspective. In the situation of increasing "liquefaction" or "melting" of structures, a human being may perceive it as liberty, independence from structures, freedom to easily change conditions of living, however, for him/her it may also mean being doomed to permanent uncertainty. It depends on whether the individual is ready to use this situation and actively create those conditions by smooth self-positioning in the changing network of possibilities (as Bill Gates, mentioned by Bauman as an example) or whether he/she is constantly being surprised by the changing rules and the disintegration of structures and has to adjust to them in order to survive. Anyhow, in both cases the human being of our times appears as a boat on a rough sea or - better - on a river, where everything flows and anything may happen. Such a human being is (or has to be in order to survive) flexible, ready for new conditions and at the same time for losing what he/she already has. On the other hand, in the situation of opposition to liquidity the human being feels safer and more confident, although stability makes him/her prone to resignation from many possibilities (i.e. from greater freedom). At the same time, to oppose liquefaction, such a human being supports the creation of stable structures and cooperates with others to save them. Because the world is changing, these structures are constantly modified, but they persist. Such a human being may be depicted as a boat on a river which joins with others to create a great raft and to finally either drop the anchor or stand on stilts, or sail together to a specified harbour.

\section{Hypermodernism as over-modernism}

My last statement is that we have gone beyond postmodernity or postmodernism and have reached over-modernity (hypermodernity) or over-modernism 
(hypermodernism). Postmodernity or - according to Wolfgang Welsch - "postmodern modernity" ${ }^{25}$ is a concept which can still be applied to describe some phenomena of today's culture and societies, but in my opinion this concept is no longer useful to characterise the people's dominant attitudes in the present times.

If we refer to the theories showing postmodernity as after-modernity which was much faster than before and liquid, we can revoke the arguments given above to justify the first two statements presented in this paper and to show that at least for practical reasons the world in the end did not plunge into liquidity or any crazy rush.

And if we understand postmodernity as times marked by the spirit of postmodernism, as defined by Jean-François Lyotard, Gianni Vattimo and other philosophers, opposed to the spirit of modernism which is based on faith in reason, progress, absolute knowledge and on metaphysical inclinations to discover unchangeable laws of reality, willing to unmask metanarratives and appreciating plurality of views and equality of interpretations, ${ }^{26}$ then - in my opinion - practical functioning needs to reconcile modernistic tendencies with the critique conducted by postmodernism. Generally speaking, the purely postmodern approach excludes treating any narrative or project seriously; within such framework no one should believe that a certain narrative is accurate and true, as it is only one of the possible narratives. The only generally basic project is to maintain le différend in order to avoid totalisation and terror ${ }^{27}$ and keep up the suspicion and distrust or "incredulity" towards metanarratives. ${ }^{28}$ Of course, such an attitude allows working, creating and building, but it is deprived of any conviction. One does something for a given reason, but as he/she distrusts any narrative which justifies this action, it will be not internalised and can be abandoned if the reason to continue this action expires. Whereas if a person strongly believes in some principle, e.g. being responsible, keeping to contracts, performing tasks reliably, he/she is referring to some narrative (let us say in this case: some work-ethos) which justi-

25 W. Welsch, Unsere postmoderne Moderne, VCH, Weinheim 1991.

26 To quote his most commonly known works: J.-F. Lyotard, La Condition postmoderne: rapport sur le savoir, Minuit, Paris 1979 (in English: The Postmodern Condition: A Report on Knowledge, transl. G. Bennington, B. Massumi, Manchester University Press, Manchester 1984); J.-F. Lyotard, Le Postmoderne expliqué aux enfants: Correspondance 1982-1985, Galilée, Paris 1988.

27 J.-F. Lyotard, Qu'est-ce que le postmodernisme?, in: J.-F. Lyotard, Le Postmoderne expliqué...; see in: J.-F. Lyotard, Answering the Question: What Is Postmodernism?, transl. R. Durand, in: J.-F. Lyotard, The Postmodern Condition..., appendix, pp. 81-82.

28 J.-F. Lyotard, The Postmodern Condition..., p. xxiv. 
fies (as a final justification) such a principle and this person distinguishes such a narrative as a fundamental one.

Such an attitude is not postmodern. Such a person may be aware that other people can refute this narrative and may think that they have the right to have and proclaim their own opinions. He or she may even be self-suspicious, saying "perhaps I am wrong in my beliefs and perhaps somewhere I interpret reality mistakenly". In spite of it, at the same time such a person will believe that generally he/she has chosen the right way and that he/she is more or less grasping the truth. ${ }^{29}$ I propose to call such an attitude "hypermodernism". And if we agree that it is dominant for our times, let us - on this basis - call them hypermodernity.

This attitude is modernistic, as it adopts fundamental narratives in which we believe, but at the same time it adopts a correction of the part of postmodernism which teaches us about conditions and limitations of our cognition and tendencies to totalise. I call it "hypermodernism", because it is above (Greek: hyper) the opposition between modernism on the one hand and postmodernism, understood as a negation of some crucial modernistic dominants, on the other hand. I presented this idea with Witold Zakrzewski in 2012 in the following way:

Thus understood hypermodernism is something above modernism, as well as something above postmodernism. While abstracting from the essential properties of modernism, it also abstracts from the negation of postmodernism (regardless of whether postmodernism is a phase of modernism or its successor). So, it is above the level of the opposition represented by these two trends. If the condition and mentality of the modernist man is characterised by certainty of knowledge (irrefutable metanarratives), the absoluteness of view and the defiance which follows from it, the primacy of the subject and the idea of progress, and the postmodernist man is characterised by their negation, then hypermodernism rises above both of them, at the same time somehow combining in itself these incompatible antitheses. ${ }^{30}$

29 Let us remark that this attitude does not fit Rorty's "liberal ironist", as "she does not think that her vocabulary is closer to reality than others, that it is in touch with a power not herself", she cannot take any idea seriously and thus build any kind of programme; the only objective phenomenon on which she may build any policy to act for public purposes is humiliation which she wants to avoid, and nothing more (cf. R. Rorty, Contingency, Irony, and Solidarity, Cambridge University Press, Cambridge-New York 1989, pp. 74-77, 90-91).

30 M. Trepczyński, W. Zakrzewski, Hipermodernizm? - perspektywy po-modernistyczne i po-postmodernistyczne, in: Refleksje na temat ponowoczesności, ed. M. Lubecki, Libron, Kraków 2012, p. 108. 
This attitude differs from what Augé or Lipovetsky and Charles have called the hypermodern, as they focused more on the phenomena of excesses and generally tried to conduct anthropological analyses, whereas, in my opinion, within philosophical reflection (referring to Lyotard, Vattimo, Welsch and others) such a definition of hypermodernism is more accurate.

This attitude is close to what is referred to as "metamodernism". In some approaches it may be considered to mean the same thing. But if we compare it with the concept presented by Vermeulen and van den Akker, we can record some differences. These two authors refer to the Greek notion of metaxis (Greek: between) and propose to understand metamodernism as being both modern and postmodern and at the same time as being neither this nor that. As they claim, on the epistemological level metamodernism uses the Kantian "as-if" strategy ("as if it were the story of mankind's development"), searching "forever for a truth that it never expects to find". And on the ontological level it "oscillates between the modern and the postmodern", "between a modern enthusiasm and a postmodern irony, between hope and melancholy, between naïveté and knowingness, empathy and apathy, unity and plurality, totality and fragmentation, purity and ambiguity", where this oscillation is not a balance, but a swing of a pendulum between innumerable poles: "Each time the metamodern enthusiasm swings toward fanaticism, gravity pulls it back toward irony; the moment its irony sways toward apathy, gravity pulls it back toward enthusiasm". Vermeulen and van den Akker refer to it as a kind of "informed naivety" and "pragmatic idealism". ${ }^{31}$

What I propose to call "hypermodernism" shares this attitude, but first of all is founded on the epistemological and ontological situation of being already beyond and over (not in between) those opposite poles. Hence, a hypermodernist does not swing, but steadily believes - is at the same time convinced and also aware that he/she may be wrong and that in the domain of narratives, language games and the many conditions of cognition there are a lot of traps. Hypermodernism is not an oscillation then, but a reconciliation possible thanks to a kind of distance and a being-above.

In practice, hypermodernists will choose their life-goals and base their actions on some narrative, just like the modernists, but having done their postmodern homework they will be cautious not to fall into some major trap. Secondly, while metamodernism seems to be establishing a way despite there being

${ }_{31}$ T. Vermeulen, R. van den Akker, Notes..., pp. 5-6. 
no goal, ${ }^{32}$ hypermodernism believes there are some absolute truths, although we can never be totally sure about them. In comparison with the labels mentioned above, it could be called a kind of optimistic idealism and a modest/self-critique/ informed realism. However, if we do so and compare hypermodernism with traditional philosophical positions like scepticism, relativism, idealism and realism, let us underline that it should not be reduced to these positions. One should not define it simply as a kind of mixture of them, for instance as idealistic realism, sceptical realism or relativistic realism. We need to bear in mind that this attitude is an end-point of the experience of the modernist spirit which went through the postmodernist critique in a Hegelian manner. The meaning of this concept should include this history.

We should consider here a possible objection to the concepts of hypermodernism and hypermodernity, based on an assumption that we still live in modernity and still are modern. I share this assumption, and at the same time I claim that it is compliant with the concepts of hypermodernism and hypermodernity. Let us refer to the conceptual framework provided by Welsch who talked about "postmodern modernity" and some phenomena like modernism and postmodernism existing within modernity. Similarly, we can speak about hypermodernity as something within modernity that is above both modernism and postmodernism and that transcends postmodernism but does not leave modernity behind. And as far as "hypermodernity" is concerned, it is also possible to understand it as a specific phase of modernity, marked by both postmodern distance and by transcending postmodernism to appreciate again what is positive in modernism, especially the modernistic faith in fighting for truth and for what is better, and the modernistic will to build and create. Furthermore, as it is commonly claimed (or at least by Welsch) that modernity contains an internal negation or will to negate, we could say that hypermodernity is, at the current stage, the most mature (as the most self-conscious) phase of modernity, consciously taking into account both the positive and negative aspects of modernity.

Finally, we should note that besides the above-described philosophical consequences of accepting the hypermodern approach (understood as above) by human beings, it is also necessary to address another extremely important philosophical problem which is crucial in the context of postmodernism, namely the attitude to

32 "Metamodernism moves for the sake of moving, attempts in spite of its inevitable failure; it seeks forever for a truth that it never expects to find” (T. Vermeulen, R. van den Akker, Notes..., p. 5). 
the concept of truth. For postmodern critique the concept of truth is elusive, or in other words truth as such does not exist. Hence, the so-called truth criteria are only some individual (subjective) assumptions valid for personal truth, but there can never be any objective (real) truth. As far as hypermodernists are concerned, we could say that, as they believe that there is some absolute or objective truth, they can accept some personal truth criteria, based on their special experience. We could even speak about some mystic criteria, for instance in the way Ludwig Wittgenstein understood it in thesis 6.522 of his Tractatus logico-philosophicus. Hovever, the hypermodernists probably will not discover any final self-justifying criteria for finding out what is true. That is to say that a hypermodernist may believe that his/her truth criteria lead to the truth, but he/she cannot be sure about that and for this reason he/she would rather refrain from offering them to others.

However, let us note that while people may conduct endless discussions about what is true, there is some common sense of what is absolutely false. It can be experienced when generally people agree that something is a lie, i.e. when they can objectively prove it is false. This experience could represent a kind of criteria that could be shared by people as something objective, so it could constitute objective criteria for hypermodernists. However, it should rather be called falsity criteria or negative-truth criteria, as truth about a lie is truth about negation (we could note it down as: $\mathrm{T}(\neg \mathrm{p})$ ). This approach is similar to what Umberto Eco presented as negative realism. ${ }^{33}$ It is also very similar to Karl Popper's logic of scientific discovery in which what we can be sure about is that something occurred to be false. ${ }^{34}$ And going along with Popper's ideas, we could introduce the concept of "light truth" or "soft truth". It could be defined as a statement which after relatively many tests was not falsified (hence: "corroborated"), so it is perceived to be a reliable one. It could be then considered a good candidate for an absolute or objective truth, however, it is taken into account that the only positive truth criteria can only be personal (subjective).

Finally, we should note that such a hypermodern attitude to truth is extremely important in facing the challenge of the last decade which is the phenomenon

33 U. Eco, Il realismo minimo, "La Repubblica", 11.03.2012, URL: https://ricerca.repubblica.it/repubblica/archivio/repubblica/2012/03/11/il-realismo-minimo.html. Cf. a short note: M. Trepczyński, Realizm negatywny według Eca, in: Piknik z filozofia włoską, red. G. Rogowska, M. Trepczyński, Wydawnictwo Campidoglio, Warszawa 2013, pp. 88-89.

34 Cf. K. Popper, The Logic of Scientific Discovery, Taylor \& Francis e-Library 2005, pp. 4-7, 248-252. 
and the concept of post-truth. Although it has already been widely described and discussed, ${ }^{35}$ it may seem that we are still defenceless against the attacks of media and politicians saying anything, no matter whether it has any meaning or not and whether it is true or false. However, when postmodernists in fact have no tool to oppose it, as - in my opinion - "post-truth" is logically combined with the postmodern attitude to the concept of truth, hypermodernists do have one, which is their belief in truth. Consequently, first, what is being said always matters: hypermodernists are convinced that there is some discerned or most reasonable interpretive model according to which it is possible to judge whether a sentence is true or false. Second, as it has been demonstrated above, by using negative-truth criteria they are able to refute what is certainly false. In this way, within their approach, they disarm or even (at least for themselves) annihilate the phenomenon (on the practical level) and the concept (on the intellectual level) of post-truth. Of course, practical problems can occur when one is dealing with the phenomenon of "fake news", which is closely related to the concept of posttruth. Very often it is difficult to verify or falsify what is broadly distributed in the media. However, the strong belief of hypermodernists that there is objective truth and that it is possible to detect what is false helps them to make an effort to check information which seems important, compare it with other news coming from various sources and cooperate with others to find out what is true. In practice, the main obstacles to knowing the truth (at least "negative truth") are lack of criticism and the attitude that everybody can have their own truths. In this light, hypermodernism can also be a good way of dealing with such contemporary challenges as post-truth and fake news.

\section{Conclusion}

Within modernity we can distinguish many characteristic trends. In my opinion, one of them is a tendency to exaggerate. I think that the last decades of the 20th century were times of exaggeration and the first two decades of the 21st century have been in fact times of reflection and also reaction to many examples of this exaggeration. We can identify opposition to such exaggeration on the part of

35 See e.g. M.Á. Quintana-Paz, Post-Truth as a Feature of Hypermodern Times, "Edukacja Filozoficzna" 2018, Vol. 66, No. 2, pp. 143-161. 
the market which accepts more and more technological innovations but cannot swallow them very fast, in keeping with the principle of maximal income and the nature of development which, as it appears, does not tend to be exponential, resulting in a situation in which governments or the European Union have to "enter the game" in order to speed up changes. When viewed against the background of predicted exponential growth, our times of hypermodernism (if we agree to call them so) are marked by deceleration rather than acceleration. We can also notice the opposition of social engineers, employers and also other people to the idea of liquidity - those people tend to appreciate stability, reliability and values. In this way, hypermodernism could also represent a kind of re-stabilisation. Finally, it seems that having learned from the "postmodern lesson" people still believe in objective (so independent from the knower) or even absolute (independent from anything, unconditioned) truths, opposing the consequent relativism and the final destruction of metanarratives. This is why, in my opinion, although many concepts presented at the end of the 20th century by the authors mentioned in this article can be still applied to describe some phenomena of today's culture and societies, they are insufficient in attempts to characterise the dominant tendencies in societies and the people's dominant attitudes in the present times, as such a dominant tendency could be more of a kind of reconciliation of the trends represented by modernism and postmodernism. Finally, as I tried to show, hypermodernism can help in dealing with postmodern problems with the concept of truth and with the contemporary challenge of post-truth. This is why I dare offer a specifically understood concept of hypermodenism and hypermodernity as a tool for describing contemporary phenomena and for constructing a positive programme for the people of our times.

\section{Bibliography}

Aldrich H.E., Langton N., Human Resource Management Practices and Organizational Life Cycles, in: Frontiers of Entrepreneurship Research 1997, ed. Paul Reynolds et al., Babson College, Center for Entrepreneurial Studies, Babson Park, MA 1998, pp. 349-357.

Aldrich H.E., Ruef M., Organizations Evolving, Sage Publications, London 2006. 
Aubert N. (ed.), L'Individu Hypermoderne, Eres, Ramonville-Saint-Agne 2004. Aubert N., La Société Hypermoderne, Une Société par Excès?, in: La Société Hypermoderne, Ruptures et Contradictions, ed. N. Aubert, L'harmattan, Paris 2010, pp. 23-34.

Augé M., Non-Lieux: Introduction à Une Anthropologie de la Surmodernité, Seuil, Paris 1992 [English transl.: 1995: Non-Places: Introduction to an Anthropology of Supermodernity, transl. J. Howe].

Bauman Z., Liquid Modernity, Polity Press, Cambridge 2000.

Brockerhoff M., Urban Growth in Developing Countries: A Review of Projections and Predictions, "Population and Development Review" 1999, Vol. 25, No. 4, pp. 757-778.

Charles S., L'hypermoderne expliqué aux enfants: Correspondance 2003-2006, Liber, Montréal 2007.

Clegg S., Baumeler C., Essai: From Iron Cages to Liquid Modernity in Organisational Analysis, "Organisation Studies" 2010, Vol. 31, No. 12, pp. 1-21.

Davis M., Liquid Sociology, "Sociology” 2008, Vol. 42, No. 6, pp. 1237-1244.

Eco U., Il realismo minimo, "La Repubblica", 11.03.2012, URL: https://ricerca. repubblica.it/repubblica/archivio/repubblica/2012/03/11/il-realismo-minimo. html.

Global Tolerance, The Values Revolution (report), London 2015.

Hoffmann-Burdzińska K., Rutkowska M., Work Life Balance as a Factor Influencing Well-Being, "Journal of Positive Management" 2015, Vol. 6, No. 4, pp. 87-101.

Huebner J., A Possible Declining Trend for Worldwide Innovation, “Technological Forecasting and Social Change" 2005, Vol. 72, No. 8, pp. 980-986.

Hutcheon L., The Politics of Postmodernism, Routledge, New York-London 2002. Kurzweil R., The Law of Accelerating Returns, "Kurzweil. Accelerating Intelligence: Essays", URL: https://www.kurzweilai.net/the-law-of-accelerating-returns.

Lee R.L.M., Modernity, Solidity and Agency: Liquidity Reconsidered, "Sociology" 2011, Vol. 45, No. 4, pp. 650-664.

Lipovetsky G., Charles S., Les temps hypermodernes, Grasset \& Fasquelle, Paris 2004 [English transl.: Hypermodern Times, transl. A. Brown, Polity Press 2005.]

Lyotard. J.-F., La Condition postmoderne: rapport sur le savoir, Minuit, Paris 1979. 
Lyotard. J.-F., Le Postmoderne expliqué aux enfants: Correspondance 1982-1985, Galilée, Paris 1988.

Malan D., et al., Values and the Fourth Industrial Revolution: Connecting the Dots between Value, Values, Profit and Purpose, World Economic Forum, Sept. 2016, DOI: 10.13140/RG.2.2.28917.17128.

Modis Th., Why the Singularity Cannot Happen, in: Singularity Hypotheses, ed. A.H. Eden et al., Springer, Berlin-Heidelberg 2012, pp. 311-339, DOI: 10.1007/978-3-642-32560-1_16.

Popper K., The Logic of Scientific Discovery, Taylor \& Francis e-Library 2005.

Rorty R., Contingency, Irony, and Solidarity, Cambridge University Press, Cambridge-New York 1989.

Rudel Th.K., Hooper L., Is the Pace of Social Change Accelerating? Latecomers, Common Languages, and Rapid Historical Declines in Fertility, "International Journal of Comparative Sociology" 2005, Vol. 46, No. 4, pp. 275-296, DOI: 10.1177/0020715205059204.

Quintana-Paz M.Á., Post-Truth as a Feature of Hypermodern Times, "Edukacja Filozoficzna" 2018, Vol. 66, No. 2, pp. 143-161.

Toth J., The Passing of Postmodernism: A Spectroanalysis of the Contemporary, SUNY Press, Albany 2010.

Trepczyński M., Realizm negatywny według Eca, in: Piknik z filozofia włoska, red. G. Rogowska, M. Trepczyński, Wydawnictwo Campidoglio, Warszawa 2013, pp. 88-89.

Trepczyński M., Zakrzewski W., Hipermodernizm? - perspektywy po-modernistyczne i po-postmodernistyczne, in: Refleksje na temat ponowoczesności, ed. M. Lubecki, Libron, Kraków 2012, pp. 77-115.

Vermeulen T., van den Akker R., Notes on Metamodernism, "Journal of Aesthetics \& Culture" 2010, Vol. 2, No. 1, 5677, DOI: 10.3402/jac.v2i0.5677.

Węgierski M., The Dilemma of Hypermodernity, "Perspectives" 1992, Vol. 5 [Polish transl.: Dylemat hipermodernizmu, "Zielone Brygady. Pismo ekologów" 1993, No. 4], available online: http://literatefreedom.org/dilemma-of-hypermodernity.

Welsch W., Unsere postmoderne Moderne, VCH, Weinheim 1991.

Wittgenstein L., Tractatus logico-philosophicus, Harcourt, Brace, New York 1922. 


\section{Summary}

In this paper I refer to and comment on some diagnoses concerning the current state of modernity. I present and argue three statements: 1) today's modernity is not accelerated, but decelerated; 2) today's "liquid" modernity seems to be seeking fixed points; 3) we went beyond postmodernity or postmodernism to reach over-modernity (hypermodernity) or over-modernism (hypermodernism). Within the considerations devoted to the last thesis I offer my own definition of hypermodernism (as a kind of reconciliation of modernism and postmodernism) and discern it i.a. from metamodernism. In the last part I also briefly outline the problem of truth in the hypermodern approach.

Keywords: modernism, postmodernism, hypermodernism, hypermodernity, liquid modernity

\section{Streszczenie}

\section{Hipermodernizm jako spowolnienie, restabilizacja i pojednanie}

W artykule tym odnoszę się do głównych diagnoz dotyczących obecnego stanu nowoczesności. Prezentuję i argumentuję trzy następujące tezy: 1) dzisiejsza nowoczesność nie jest przyspieszona, lecz spowolniona; 2) dzisiejsza "płynna” nowoczesność zdaje się poszukiwać stałych punktów, 3) wykroczyliśmy poza ponowoczesność lub postmodernizm, wkraczając w nadnowoczeność (hipernowoczeność) lub nadmodernizm (hipermodernizm). W ramach rozważań nad ostatnią z tych tez przedstawiam własną definicję hipermodernizmu (jako pojednania modernizmu z postmodernizmem), odróżniając go m.in. od metamodernizmu. W ostatniej części pokrótce zarysowuję też problem prawdy w ujęciu hipermodernistycznym.

Słowa kluczowe: modernizm, postmodernizm, hipermodernizm, hipernowoczesność, płynna nowoczesność 